\title{
Study the effects of various growth regulator and crop architecture on Valeriana jatamansi - Crop raised through seed: valuable medicinal herb of Eastern Himalaya range
}

Dhiman Mukherjee

Bidhan Chandra Krishi Viswavidayalaya, Directorate of Research, Kalayani-741235, India.

Received: March 25, 2016; Revised: March 28, 2016; Accepted: April 15, 2016.

\begin{abstract}
An experiment was carried out during the year of 2010 - 2013 at Algarah farmer field (1740 m asl), under the aegis of Uttar Banga Krishi Viswavidyalaya, to evaluate the effect of different growth hormone on seed germination of jatamansi, and assess the effect of date of transplanting and plant geometry on its economic and biomass production under the mid hill condition of West Bengal. An experiment was with various growth regulators on Valeriana jatamansi revealed that maximum seed germination was observed with $\mathrm{KNO}_{3}(0.2 \%)(70.00 \pm 1.10)$, and significantly superior to rest of the hormonal treatments except Kinetin 200 $\mathrm{ppm}$. This recorded $124 \%$ more seed germination over the control. GA $200 \mathrm{ppm}$ took least time to start germination and was at par with Kinetin $200 \mathrm{ppm}$ and $\mathrm{KNO}_{3}(0.2 \%)$ treated seed. Transplanting of seedling during the first week of July gave significant response on fresh aerial biomass ( $\mathrm{g} / \mathrm{plant}$ ) at 6 months only. However, plant spacing gave significant response all the stage of observation, and maximum aerial biomass was recorded with spacing of $30 \times 45 \mathrm{~cm}$, and was at par with $30 \times 30 \mathrm{~cm}$ plant spacing. Maximum underground biomass was recorded with July transplanting with $30 \times 45 \mathrm{~cm}$. Maximum underground rhizome biomass was recorded with $30 \times 45 \mathrm{~cm}$ spacing, and was at par with $30 \times 30 \mathrm{~cm}$ spacing at 9 and 18 -month stage of observation. Root biomass failed to produce any significant response with time of transplanting. However, maximum root biomass was recorded with July transplanting. More root growth was recorded with $30 \times 45 \mathrm{~cm}$ and was at par with $30 \times 30 \mathrm{~cm}$ spacing during 15 and 18-month observation.
\end{abstract}

Key words: Valeriana jatamansi; Algarah; Medicinal herb

\section{Introduction}

Valeriana jatamansi is one of the most important medicinal herb of the western to eastern Himalayan grown at an altitude of $1200-2000 \mathrm{~m}$. It is distributed from Afghanistan to southwest China, Burma and few part of Indian Himalayan range. Like many other non-timber forest products (NTFPs), this vulnerable plant (Valeriana jatamansi Jones; Syn. Valeriana wallichi) is taken as forest gift and hence there is neither any control system in its harvest nor its domestication. Locally it is being used for medicinal purpose especially for headache and eye trouble. In Ayurvedic medicine, it is used as aromatic, stimulant, carminative, and antispasmodic. It is also used for the treatment of epilepsy and hysteria. Powdered drug, mixed with sugar is used in urinary troubles. A decoction of the drug is reported to be given in Nepal to mothers after parturition, probably as a sedative. Although the economic value of the herb was reportedly unknown to the local people until recent past, the herb has now been widely known for its market potential (Mukherjee et al., 2013). Thus, the exploitation of this plant is increasing leading to its rapid decline from its natural habitat in Himalayan range. Valariana jatamansi inhabit diverse habitats of Darjeeling - Sikkim Himalaya, so it was thought worthwhile to undertake detailed plant behaviour that enables the species to survive in these varied habitats. Some pocket of North $\backslash$ Sikkim few species of this valuable medicinal plant observed. The species witnessed a

\section{Corresponding Author}

\section{Dr. Dhiman Mukherjee,}

Ex- Officer Incharge, Medicinal Plant Unit, Kalimpong.

Associate Professor (Agronomy),

Officer In-charge, AICRP on Wheat and Barley Improvement,

Directorate of Research, B.C.K.V,

Kalyani -741235, WB (India). tremendous decline in its population size due to its poor seed germination percentage (Sharma et al., 2005). It tells the tale of biotic interferences, which have brought it to the brink of extinction. If left as such and exploited at the same rate, in near future, the species will disappear forever. Rhizome is an item of commerce and is being sold to different trading centres in the region. Farmer's or inhabitant of different forest location, particularly in Eastern Himalaya, as per our survey revealed that, they could not know how to improve its production, agronomic package and conservation of this valuable treasure of this earth. Our observation revealed that, date of planting (crop raised through seed) plays an important role in productivity of Valeriana jatamansi. Drastic reduction in yield of seed and rhizome has been recorded with the delay of sowing beyond optimum time May - July. Late sown exposed to both the extreme of temperature. i.e. low temperature during early growth period, which restrict the vegetative phase and high temperature during post vegetation phase of life cycle, which reduce the duration of rhizome and root development and consequently the crop yield as a whole (Mukherjee, 2009). Till date very little work has been conducted on this plant particularly enhancement of seed germination, and proper agronomic manipulation for high yield etc. Keeping this aspect in mind, present work was undertaken to examine influence of various 
growth hormone on seed germination of Valeriana jatamansi. Further study made on influence planting time and crop configuration on growth habitats and economic production, of this high value rare medicinal plant of Darjeeling himalaya. Statistical calculation made as per normal procedure adopted from Gomez and Gomez (Gomez and Gomez, 1984).

\section{Materials and Methods}

An experiment was carried out during the year of 2010 - 2013 with the objective of to find out influence of plant growth hormone on seed germination (at Algarah field: 1740 masl) of this high value rare medicinal plant of Darjeeling Himalaya and consequence of sowing date and planting geometry on growth and economic yield of Valeriana jatamansi at Algarah farmer field, under the aegis of Uttar Banga Krishi Viswavidyalaya. Planting materials for this experiment was mainly raised from seed which, collected from lava forest. Seed was chosen for experiment, keeping in mind that, this would help easy to propagate and farmer friendly also. The soil of the experimental site was sandy loam having pH 5.3 with moderate available nitrogen, phosphorus and potassium (Jackson, 1973). Analyzed soil sample data presented in Table 1.

Table 1: Physico-chemical status of soil sample from Algarah farmer field (Lava, Kalimpong Block II) used for the germination of seed of Valeriana jatamansi

\begin{tabular}{|c|c|c|c|c|c|c|c|c|}
\hline \multirow{2}{*}{$\mathrm{pH}$} & \multirow{2}{*}{ ECE (inch/cm) } & \multicolumn{3}{|c|}{ Available (kg/ha) } & \multirow{2}{*}{ Total N (\%) } & \multirow{2}{*}{ Organic C (\%) } & \multirow{2}{*}{$\begin{array}{c}\text { Organic matter } \\
(\%)\end{array}$} & \multirow{2}{*}{$\mathrm{C} / \mathrm{N}$ ratio } \\
\hline & & $\mathbf{N}$ & $\mathbf{P}_{2} \mathbf{O}_{5}$ & $\mathrm{~K}_{2} \mathrm{O}$ & & & & \\
\hline 5.3 & 0.30 & 311 & 24.1 & 294 & 14.12 & 3.14 & 2.74 & 13.45 \\
\hline
\end{tabular}

Mature seed were collected during end of February, 2009 and March 2010, and kept in paper bags of convenient size after proper labelling. The fruit were shed dried in the open air and gently hand shaken while inside the paper bag. The minute clean seeds fall and settle in the bottom of paper bag. These fallen seeds were collected and stored in an open container. This process was repeated till the seed were almost fully collected. Finally, the remaining fruits (some left over seeds) were hand crushed and passed through a fine nylone sieved and stored in a separate but similar container. This contains impurities like vegetative, clay particles and other foreign materials of almost similar size. This seed material was kept in desiccators with silica gel to avoid moisture absorption. During the investigation, seed were surface sterilized by dipping them in $0.5 \%$ aqueous solution of $\mathrm{HgCl}_{2}$ for $2 \mathrm{~min}$ to remove bacterial and fungal contamination and then rinsed thoroughly (four times) with distilled water and then soaked in different concentration of growth regulators for $15 \mathrm{hr}$ and place in a glass plate for shed dry. Viability test using 2,3,5, Triphenyle tetrazolium chloride solution could not be performed in lab. The seeds were so small that the embryo could not be detached to observe the staining pattern. Experiments was made for seed germination investigation under field condition at Algarah farmer field, with 200 seeds was taken with triplicate in appropriate bed size inside a polyhouse to standardized best treatments for maximum germination. Sowing of seed in a nursery bed was done under careful observation with finally sieved and well sterilized (in autoclave) clay soil in the $10^{\text {th }}$ and $16^{\text {st }}$ April, respectively in 2009 and 2010. Meteorological data indicate that during these months' day - night temperature of the experimental sites varied between 7 and $23^{\circ} \mathrm{C}$, probably meeting the optimum temperature requirement of this species and resulting in higher germination with less time for completion. Seed germination under different hormonal treatments, i.e. control along with sterilized soil mixed with $\mathrm{GA}_{3} 100$ ppm, GA 150 ppm, GA 200 ppm, Kinetin 100 ppm, Kinetin200 ppm, Kinetin 300 ppm, $\mathrm{KNO}_{3}(0.1 \%), \mathrm{KNO}_{3}(0.2 \%)$ and $\mathrm{KNO}_{3}$ $(0.3 \%)$. Seed germination potential under different treatments set were tested using randomized block design with appropriate statistical tools. Further, one field experiment was conducted at Algarah farmer field, with (crop raised through seed) split plot design with five replications, having time of sowing in main plot, which includes viz. first week of June (S1) and first week of July (S2) planting and three crop geometry pattern subplot viz. $30 \times 20 \mathrm{~cm}$ (P1), $30 \times 30 \mathrm{~cm}(\mathrm{P} 2)$ and $30 \times 45 \mathrm{~cm}$ (P3). The irrigation was given and other recommended packages of practice were adopted during the crop growth period in both the years. Data on growth pattern was taken at 3 month intervals as per normal procedure. The significant differences between the treatments were compared with the critical difference (CD) at $5 \%$ level of probability (Gomez and Gomez. 1984).

\section{Result and Discussion}

Seed germination study revealed significant improvement in germination percentage with kinetin and $\mathrm{KNO}_{3}$ treatment compared to control (Table 2). Amongst all hormonal treatments, maximum seed germination was observed with $\mathrm{KNO}_{3}(0.2 \%)(70.00 \pm 1.10)$, and significantly superior to rest of the hormonal treatments except Kinetin 300 ppm. This recorded $127 \%$ more seed germination over the control. GA 200 ppm took least time to start germination and was at par with Kinetin 200 ppm and $\mathrm{KNO}_{3}(0.2 \%)$ treated seed. However, days required for completion for germination was faster with $\mathrm{GA}_{3} 200 \mathrm{ppm}$ and was followed by $\mathrm{KNO}_{3}(0.3 \%)$ treated seeds. Nearly 20-39 percent reduction was observed in 
germination when the concentration of Kinetin and $\mathrm{KNO}_{3}$ decreases. With growth regulators, $\mathrm{GA}_{3}$ application gave less percentage of seed germination compared to other growth regulator treatments.

Transplanting of seedling during the first week of July gave significant response on fresh aerial biomass (g/plant) at 6 months only and failed to produce any significant response rest of the phase of observation (Table 3). However, plant spacing gave significant response all the stage of observation, and maximum aerial biomass was recorded with spacing of $30 \times 45 \mathrm{~cm}$ and was at par with $30 \times 30 \mathrm{~cm}$ plant spacing all the stage except at 15 -month observation. Least biomass was recorded with close spacing seedlings. Fresh underground biomass ( $\mathrm{g} /$ plant) failed to produce any significant response on date of transplanting all stages except at 12 month. Maximum underground biomass was recorded with July transplanting. Further, our study revealed that plant spacing produce significant response on fresh underground biomass at all stages except 9 months.

Table 2: Effect of different hormonal treatments on seed germination of Valeriana jatamansi.

\begin{tabular}{lccc}
\multicolumn{1}{c}{ Treatments } & Germination (\%) & $\begin{array}{c}\text { Days require for } \\
\text { onset of germination }\end{array}$ & $\begin{array}{c}\text { Days required for } \\
\text { completion of germination }\end{array}$ \\
\hline $\mathrm{GA}_{3} 100 \mathrm{ppm}$ & $27.00 \pm 1.32$ & 27.00 & 34.00 \\
$\mathrm{GA}_{3} 150 \mathrm{ppm}$ & $63.15 \pm 1.03$ & 17.03 & 24.13 \\
$\mathrm{GA}_{3} 200 \mathrm{ppm}$ & $28.10 \pm 3.09$ & 9.06 & 13.00 \\
$\mathrm{Kinetin} 100 \mathrm{ppm}$ & $49.00 \pm 2.01$ & 25.00 & 34.33 \\
Kinetin $200 \mathrm{ppm}$ & $58.66 \pm 3.72$ & 19.53 & 27.10 \\
$\mathrm{Kinetin} 300 \mathrm{ppm}$ & $68.66 \pm 1.01$ & 17.33 & 21.66 \\
$\mathrm{KNO}_{3}(0.1 \%)$ & $27.01 \pm 0.31$ & 24.13 & 33.00 \\
$\mathrm{KNO}_{3}(0.2 \%)$ & $70.00 \pm 1.10$ & 11.13 & 30.13 \\
$\mathrm{KNO}_{3}(0.3 \%)$ & $38.15 \pm 1.02$ & 15.32 & 23.69 \\
$\mathrm{Control}$ & $34.19 \pm 2.02$ & 28.03 & 35.16 \\
$\mathrm{CD}(\mathrm{p}=0.05)$ & 6.08 & 3.98 & 4.01 \\
\hline
\end{tabular}

underground rhizome biomass was recorded with

Maximum underground biomass was recorded with $\mathrm{P}_{3}(30 \times 45 \mathrm{~cm})$ at all the stage and was at par with $\mathrm{P}_{2}(30 \times 30 \mathrm{~cm})$ during 15 and 18-month study (Table 4). Date of transplanting failed to produce any significant effect on fresh underground rhizome biomass except at 9-month stage. However, maximum rhizome biomass was recorded with July planting seedlings. Further, our observation revealed that plant spacing gave significant response at all the stage of studies except at 15 month intervals. Maximum
$30 \times 45 \mathrm{~cm}$ spacing and was at par with $30 \times 30 \mathrm{~cm}$ spacing at 9 and 18-month stage of observation (Table 5). Root biomass failed to gave any significant response with time of transplanting. However, maximum root biomass was recorded with July transplanting (Table 6). Plant spacing gave significant effect on root biomass at all stage except at 9-month observation. More root growth was recorded with $30 \times 45 \mathrm{~cm}$ and was at par with $30 \times 30 \mathrm{~cm}$ spacing during 15 and 18-month observation.

Table 3: Effect of time of transplanting and planting geometry on fresh aerial biomass ( $\mathrm{g} / \mathrm{plant})$

\begin{tabular}{cccccc}
\hline Treatments & $\mathbf{6}$ months & 9 months & 12 months & 15 months & 18 months \\
\hline Transplanting time & & & & & \\
$\mathrm{S}_{1}$ (July) & 3.1 & 6.34 & 15.87 & 37.27 & 42.69 \\
$\mathrm{~S}_{2}$ (Aug) & 2.22 & 5.20 & 15.16 & 34.30 & 42.46 \\
SEm \pm & 0.27 & 0.82 & 1.61 & 2.56 & 11.15 \\
$\mathrm{CD}(\mathrm{p}=0.5)$ & 0.61 & $\mathrm{NS}$ & $\mathrm{NS}$ & $\mathrm{NS}$ & $\mathrm{NS}$ \\
Plant spacing & & & & & \\
$\mathrm{P}_{1}(30 \times 20 \mathrm{~cm})$ & 2.09 & 4.09 & 7.22 & 23.00 & 24.51 \\
$\mathrm{P}_{2}(30 \times 30 \mathrm{~cm})$ & 2.63 & 6.26 & 17.69 & 36.71 & 45.81 \\
$\mathrm{P}_{3}(30 \times 45 \mathrm{~cm})$ & 3.27 & 6.97 & 21.62 & 47.65 & 57.30 \\
SEm \pm & 0.33 & 1.08 & 1.98 & 3.17 & 6.13 \\
$\mathrm{CD}(\mathrm{p}=0.5)$ & 0.74 & 2.24 & 4.41 & 7.07 & 13.66 \\
\hline
\end{tabular}

Table 4: Effect of time of transplanting and planting geometry on fresh underground biomass (g/plant)

\begin{tabular}{cccccc}
\hline Treatments & 6 months & 9 months & 12 months & 15 months & 18 months \\
\hline Transplanting time & & & & & \\
S $_{1}$ (July) & 1.62 & 3.90 & 8.18 & 24.05 & 53.80 \\
$\mathrm{~S}_{2}$ (Aug) & 1.46 & 4.55 & 7.48 & 20.52 & 46.63 \\
SEm \pm & 0.18 & 0.56 & 0.31 & 2.30 & 4.96 \\
CD $(p=0.5)$ & $\mathrm{NS}$ & $\mathrm{NS}$ & 0.71 & $\mathrm{NS}$ & $\mathrm{NS}$ \\
Plant spacing & & & & & \\
$\mathrm{P}_{1}(30 \times 20 \mathrm{~cm})$ & 1.03 & 3.85 & 6.17 & 17.57 & 30.77 \\
$\mathrm{P}_{2}(30 \times 30 \mathrm{~cm})$ & 1.44 & 4.27 & 7.48 & 22.98 & 56.66 \\
$\mathrm{P}_{3}(30 \times 45 \mathrm{~cm})$ & 2.15 & 4.56 & 9.48 & 26.73 & 63.23 \\
SEm \pm & 0.22 & 0.69 & 0.38 & 2.82 & 6.07 \\
$\mathrm{CD}(\mathrm{p}=0.5)$ & 0.50 & $\mathrm{NS}$ & 0.85 & 6.20 & 13.53 \\
\hline
\end{tabular}


Table 5: Effect of time of transplanting and planting geometry on fresh underground rhizome biomass (g/plant)

\begin{tabular}{|c|c|c|c|c|c|}
\hline Treatments & 6 months & 9 months & 12 months & 15 months & 18 months \\
\hline \multicolumn{6}{|c|}{ Transplanting time } \\
\hline $\mathrm{S}_{1}$ (July) & 0.45 & 1.19 & 2.7 & 10.40 & 19.36 \\
\hline $\mathrm{S}_{2}$ (Aug) & 0.38 & 1.12 & 2.6 & 9.66 & 17.25 \\
\hline SEm \pm & 0.03 & 0.13 & 0.23 & 0.95 & 1.97 \\
\hline $\mathrm{CD}(\mathrm{p}=0.5)$ & NS & 0.31 & NS & NS & NS \\
\hline \multicolumn{6}{|l|}{ Plant spacing } \\
\hline$P_{1}(30 \times 20 \mathrm{~cm})$ & 0.27 & 1.17 & 2.34 & 8.35 & 13.06 \\
\hline $\mathrm{P}_{2}(30 \times 30 \mathrm{~cm})$ & 0.40 & 1.08 & 2.52 & 10.11 & 19.80 \\
\hline $\mathrm{P}_{3}(30 \times 45 \mathrm{~cm})$ & 0.57 & 1.23 & 3.31 & 11.62 & 22.94 \\
\hline SEm \pm & 0.44 & 0.17 & 0.28 & 1.20 & 2.41 \\
\hline $\mathrm{CD}(\mathrm{p}=0.5)$ & 0.09 & 0.38 & 0.64 & NS & 5.37 \\
\hline
\end{tabular}

Table 6: Effect of time of transplanting and planting geometry on fresh underground root biomass (g/plant)

\begin{tabular}{|c|c|c|c|c|c|}
\hline Treatments & 6 months & 9 months & 12 months & 15 months & 18 months \\
\hline \multicolumn{6}{|c|}{ Transplanting time } \\
\hline $\mathrm{S}_{1}$ (July) & 1.06 & 2.01 & 4.05 & 13.06 & 33.85 \\
\hline $\mathrm{S}_{2}$ (Aug) & 0.93 & 1.77 & 3.46 & 11.69 & 30.56 \\
\hline SEm \pm & 0.13 & 0.41 & 0.33 & 1.53 & 3.48 \\
\hline $\mathrm{CD}(\mathrm{p}=0.5)$ & NS & NS & NS & NS & NS \\
\hline \multicolumn{6}{|l|}{ Plant spacing } \\
\hline$P_{1}(30 \times 20 \mathrm{~cm})$ & 0.69 & 1.25 & 2.49 & 9.68 & 19.38 \\
\hline $\mathrm{P}_{2}(30 \times 30 \mathrm{~cm})$ & 0.77 & 1.98 & 3.61 & 12.64 & 36.95 \\
\hline $\mathrm{P}_{3}(30 \times 45 \mathrm{~cm})$ & 1.58 & 2.43 & 5.16 & 14.81 & 40.18 \\
\hline SEm \pm & 0.16 & 0.49 & 0.40 & 1.87 & 4.26 \\
\hline $\mathrm{CD}(\mathrm{p}=0.5)$ & 0.36 & NS & 0.90 & 4.18 & 9.50 \\
\hline
\end{tabular}

\section{Conclusion}

Study revealed that, amongst various growth hormonal treatments, utmost seed germination was observed with $\mathrm{KNO}_{3}(0.2 \%)$ and Kinetin 300 ppm under high hill condition. Optimum transplanting during the first week of June with spacing of $30 \times 45 \mathrm{~cm}$ is best suited, for higher yield of herb and economic production per unit area of land. This ultimately more beneficial to growers in turn higher net return.

\section{References}

1. Gomez and A. A. Gomez. (Statistical procedure for agricultural research", $2^{\text {nd }}$ edn. John Willey \& Sons. New York, U.S.A. (1984): 241-271.

2. M.L. Jackson. Soil Chemical Analysis, Prentice Hall of India Pvt. Ltd. New Delhi, India (1973): 183204.
3. D. Mukherjee "Medicinal plant in Darjeeling hills" In: Krishi Sandesh (eds. Rai, S., Mokthan, M.W. and Ali, S). Miazik International Volunteer Center, Japan (2009): 118-121.

4. Chakraborty, Baskey and D. Mukherjee Near to extinct medicinal plants of Darjeeling hills: Protect for future. Himalayan Times 4.7 (2013): 17-18.

5. Sharma, Shanti and R. K. Sharma. Seed germination behaviour of some medicinal plants of Lahaul and Spiti cold desert: implications for conservation and cultivation. Current Science 90 (2005): 1113-1118.

\section{Cite this article as:}

Dhiman Mukherjee. Study the effects of various growth regulator and crop architecture on Valeriana jatamansi - Crop raised through seed: valuable medicinal herb of Eastern Himalaya range. Annals of Plant Sciences 5.4 (2016): 1326-1329.

Source of support: Nil

Conflict of interest: None Declared 